Article

\title{
Huebner's Critical Encounter with the Philosophy of Heidegger in Being and Time: Learning, Understanding, and the Authentic Unfolding of History in the Curriculum
}

James M. Magrini

\begin{abstract}
This paper responds to the following question: "What are the issues concerned with potential educational reform that arise from Huebner's critical encounter with Heidegger and the tradition in education and curriculum theory?" In attempting a rejoinder, I revisit Huebner's groundbreaking essay, "Curriculum as Concern for Man's Temporality," which introduces the phenomenological method in education and curriculum studies, with the goal of examining in detail the underlying themes, issues, and concepts, which ground Huebner's reconceptualization of curriculum reform, as they emerge from Heidegger's philosophy. I show that Huebner's understanding of Beingin-the-world in terms of the design of the educational environment, not only mirrors, but as well, embodies the flux, flow, and rhythmic dynamics of history's "dialectic" unfolding as a temporal phenomenon, which for Heidegger represents our authentic "historizing" in the "moment of vision," or Augenblick, and this for Heidegger is the definitive embodiment of Dasein's authentic mode of existence as historical Being-in-the-world as Being-with Others.
\end{abstract}

Key words: Heidegger, Dwayne Huebner, phenomenology, philosophy of education

his essay engages in a close reading of the concepts that Dwayne Huebner originally adopted for inclusion in his curriculum philosophy by examining the essay, "Curriculum as Concern for Man's Temporality,"1 focusing on the sources that emerge directly from Heidegger's philosophy, including the phenomenological-fundamental-ontology of Dasein

1 Pinar writes of the essay in the following manner when outlining the history of phenomenology in curriculum studies: "Dwayne Huebner introduced phenomenology to curriculum studies in the 1960s. Perhaps his 'Curriculum as Concern for Man's Temporality,' read to the 1967 Ohio State University Curriculum Theory Conference and printed in Theory into Practice, can be acknowledged as the specific event." William Pinar, "History of Phenomenology 
as it is presented in Being and Time, which will then be related back to Huebner's work through hermeneutic exegesis and critique. Three sections form this essay: (1) Huebner's critique of learning and knowledge within "traditionalist" and "concept-empiricist" curriculum ideology along with outlining a view of the human and world these aforementioned curriculum movements adopt in terms of Cartesian dualism; (2) The interpretation of ecstatic temporality as it emerges from Heidegger's thought and is assimilated by Huebner into the philosophy of curriculum with the purpose of identifying the deleterious effects the inauthentic notion of time, as a linear phenomenon, has on the education of students; and (3) The critical analysis of authentic learning and curriculum design, which is related to the unfolding of what Huebner terms the "individual-world dialectic," which consists of understanding and interpreting the world in terms of a referential totality directed toward the student's ownmost potentiality-for-Being as a member of a learning community, i.e., her authentic historical Being-in-the-world as Being-with others (bistoricity). ${ }^{2}$ I conclude each section with thoughts on the potential implication these ideas might have for the present and future conception of our educational practices. Ultimately, I attempt to formalize the role Heidegger's philosophy plays in inspiring Huebner's authentic reconceived understanding of curriculum and the human being along with the potential impact this philosophy has for a reinterpretation and reevaluation of our conceptions of knowledge, students, and learning in education.

Since this essay engages in philosophical archeology, concerned as it is with elucidating origins, it must be noted that any philosophy of education inspired by Heidegger's fundamental ontology of Being and Time requires clarification and justification at the outset. This is because the issue of metaphysics as related to contemporary democratic education continues to be heatedly debated in the philosophy of education. We must ask: Will the attempted appropriation of Heidegger's philosophy for the purpose of contemporary educational reform betray the original metaphysical project of Heidegger? Although a variety of responses have been offered by scholars, with some drawing decidedly pessimistic conclusions, I argue that it is not only possible to find value in Heidegger's thought of 1927 and early 1930s, it is possible to do so in manner that remains true to the development of his metaphysical philosophy during that historical period. ${ }^{3}$ For in 1933 , within the Rectoral Address delivered at Freiburg University, The Self-Assertion of the German University, Heidegger embraces the potential of metaphysics for

in Curriculum Studies," in Understanding Curriculum as Phenomenological and Deconstructed Text (London: Routledge, 1992), 235.

2 Huebner uses the term "historicity" as opposed to "historicality" in his essay, and this usage is consistent with Stambough's (1996) translation of Being and Time. Macquarrie and Robinson, however, use the term 'historicality'. Since I incorporate the Macquarrie and Robinson translation throughout, I use the term "historicality" when referring to Dasein's authentic process of historizing as Being-in-the-world as Being-with others.

3 James Magrini, "Worlds Apart in the Curriculum: Heidegger, Technology, and the Poietic Attunement of Literature," in Educational Philosophy and Theory (forthcoming 2012), 1-22. 
inspiring a sweeping reform of the system of higher education in Germany. Indeed, education at this time for Heidegger represents a distinctly and thoroughgoing metaphysical project. It is possible to marshal a defense of this claim by attending to the commentaries of Wolin and Lowith, both of whom, although disagreeing on the exact political implications of this document, identify the common metaphysical-ontological ground in Heidegger's philosophy of education during the early and mid-1930s.

As Wolin writes, Heidegger's conception of education, as expressed in the Rectoral Address and other political writings of the 1930s, should be read as advancing "the existential analytic of Being and Time" in terms of the ontological-existential structures of Being-towards-death, destiny, ecstatic temporality, and the authentic notion of freely choosing to choose oneself and community amid possibilities that are at once given and inherited. Heidegger conceives the entire reformation of higher education in Germany in terms of an urgent spiritual and intellectual mission. Education, as a mode of selfassertion, must above all else draw its transcendent power from the "essence of science (Wissenschaft) in its innermost necessity [...] and through science, educators and disciplines of those leaders and guardians of the fate" 5 hold the promise of inspiring the authentic bistorizing of Dasein. Wissenschaft, as employed by Heidegger in the address, contrary to the common rendering of this German term as science, or knowledge through natural science, as stated by translator William C. Lewis, is a "central motif in his important texts from 1929 to 1935 " and conceived by Heidegger as a special form of philosophical insight within which the "Seinsfrage (the question of Being) occupies its rightful pride of place." Wissenschaft as thus defined is properly understood as both spiritual and intellectual, in terms of the special sense of a "knowing resolve [wissende Entschlossenheit] toward the essence of Being."

According to Heidegger, the essence of Wissenschaft, which emerges from the concern with Being, is accompanied, and indeed preceded, by a mode of attunement that inspires Dasein's "unsheltered standing firm in the amidst of the uncertainty of the totality of being, which alone might result in an authentically transformed spiritual world." "Heidegger's inquiry into the essence of education is thus grounded in the philosophical potential of our "being gripped, which must determine and attune us"10 for our ontological-historical vocation, through which we are first able to grasp and formulate the philosophical question of Being, and this for Heidegger occurs through the "the fundamental attunement of

${ }^{4}$ Richard Wolin, The Heidegger Controversy: A Critical Reader (Cambridge, MA: MIT Press, 1998), 26.

5 Martin Heidegger, "The Self-Assertion of the German University," in The Heidegger Controversy: A Critical Reader (Cambridge, MA: MIT Press, 1998), 30.

${ }^{6}$ William C. Lewis, (translator's note) The Heidegger Controversy: A Critical Reader, 30.

${ }^{7}$ Ibid., 30.

${ }^{8}$ Carl Lowith, "The Political Implications of Heidegger's Existentialism," in ibid., 177.

${ }^{9}$ Heidegger, "The Self-Assertion of the German University," 33.

${ }^{10}$ Ibid., 33. 
philosophizing."11 Heidegger is clear that in order for the system of higher education to embrace Wissenschaft, or the philosophical understanding of our ontological potential as humans, two things are necessary:

[F]irst, the teachers and students must each in their own way be seized by the idea of science and remain seized by it. At the same time however, this concept of science must penetrate into and transform the basic forms in which the teachers and students collectively pursue their respective scholarly activities. ${ }^{12}$

As will be elucidated in this essay, in relation to what has been stated above, it is possible to interpret and understand Huebner's philosophy of education (and curriculum), which is both phenomenological and ontological in nature, as emerging from the very ground of metaphysics - specifically as defined by Heidegger in the 1929-30 lecture course, The Fundamental Concepts of Metaphysics: "Metaphysics is a questioning in which we inquire into beings as a whole, and inquire in such a way that in doing so we ourselves, the questioners, are thereby [attuned and] also included in the question, placed into question." 13

\section{Huebner's Critique of Traditional Curriculum Theory: Navigating the World of Present-at-Hand Entities}

Huebner adopts the view that learning, taken as the organizing component around which the curriculum turns is mistaken, for it is only one component within an ensemble of unique and specific concerns that should inform the school's curricular vision. However, it must be noted that Huebner is critical of the form of learning associated with social efficiency ideology, i.e., learning as a process of knowledge acquisition, linked with the current "scientific" trend in curriculum that demonstrates a "dependence on psychological language or the language of other behavioral scientists," 14 which engenders the bias in curriculum philosophy favoring "positivistic thought."15 In addition to being critical of those reducing learning to the study of metacognition, basic cognitive processes, and the transfer of knowledge to students through ever-greater hyper-efficient strategies for processing information, Huebner is also critical of curriculum design that privileges a single form of knowledge linked with scientific thematizing, which is abstract, conceptual, and serves the instrumental purpose of preparing the student for her life beyond

11 Martin Heidegger, Fundamental Concepts of Metaphysics: World, Finitude, Solitude, trans. by William McNeill (Bloomington, Indiana: Indiana University Press 1995), 9.

12 Heidegger, "The Self-Assertion of the German University, 36.

13 Heidegger, op cit., 12-13/9.

14 Dwayne Huebner, D. "Knowledge: An Instrument of Man," in The Lure of the Transcendent: Collected Essays By Dwayne E. Huebner (Mahwah, NJ: Lawrence Erlbaum Associates, 1999), 225.

15 Ibid., 225. 
the institution. In opposition to this limited view, Huebner sees the advantage in recognizing and embracing various forms of learning and knowledge in the curriculum. Although Huebner links authentic knowledge with know-how, this is not to say that it requires a "pragmatic or socially functional use,"16 rather he views authentic learning in terms of student participation in social activities within the classroom, which include getting along with others while engaged in heuristic learning experiences that enable the student to "discover who he is and what he may become."17

It is possible to interpret Huebner's authentic notion of learning, which emerges within the context of the curriculum shaped by the unfolding of the individual-world dialectic, functioning as the hub around which the reconceived notion of curriculum turns. Huebner's authentic notion of learning, as a process of understanding through interpretation and meaning-making, situates the student within the world of the curriculum wherein the classroom resembles the authentic world of Dasein as presented by Heidegger, i.e., a referential totality, or system of assignments and references, that we share intimately with others, which "lets entities be encountered in the kind of Being that belongs to involvements" 18 to which "Dasein assigns itself,"19 thus making up "the worldhood of the world." 20 Prior to analyzing Huebner's authentic notion of learning, it is best to unpack his critique of the epistemological-ontological views of both traditional curriculum-making (e. g., the Tyler rationale) and curriculum making in terms of concept empiricism, highlighted by emerging scientism, as the means by which to determine authentic student learning (e.g., Darling-Hammond, et al). Huebner's general critique of learning in education is two-fold and can be traced to both Heidegger's early phenomenological ontology of Dasein and his later philosophy relating to technology, poetic human dwelling, and the concern with authentic thinking as a meditative emersion in Being, and focuses on (1) the notion that all authentic learning might be reduced to knowledge in the form of abstract conceptualization, or scientific thematizing - calculative thought as described by Heidegger - valued for its use in manipulating and mastering objective, empirical reality, which is a view to knowledge grounded in (2) the Cartesian understanding of the human as an interiorized subject who resides at a metaphysical and epistemological remove from the objective world.

According to Huebner, within education "the language with the greatest acceptance today are those governed by or are imitations of science." 21 When learning is the focus of the curriculum within education philosophies

${ }^{16}$ Dwayne Hubner, "Curriculum as a Concern for Man's Temporality," in The Lure of the Transcendent: Collected Essays By Dwayne E. Huebner, 140.

${ }^{17}$ Ibid., 140.

18 Martin Heidegger, Being and Time, trans. by J. Macquarrie, E. Robinson (New York, NY: Harper \& Row, 1962), 119/86.

${ }^{19}$ Ibid., 119/86.

${ }^{20}$ Ibid., 119/86.

21 Dwayne Huebner, "New Modes of Man's Relation to Man," in The Lure of the Transcendent: Collected Essays By Dwayne E, Huebner, 23. 
embracing scientific instrumentalism, it is primarily understood in terms of "abstraction and generalization." 22 Educational models emerging from social efficiency ideology view authentic learning in terms of the student's ability to abstract "certain patterns of events from a specific situation or a series of like situations and transferring them to new situations." 23 This form of knowledge, according to Huebner, arises from the "imposition of a symbolic curtain or screen between the person or reality," 24 and knowledge of the world in this form, by means of abstract symbols and images, appears to give the human "more power in his encounter with and exploration of reality." 25 This represents for Heidegger the negative aspects associated with the privileging of scientific, or calculative knowledge, within our various modes of worlddisclosure, and as expressed by Young, "the more completely the world can be 'calculated' the more completely it can be controlled,"26 and thus "far from being concerned to disclose the world in its 'ownness,' science is just another disclosure of it in the 'work' - suitable way, another disclosure of it as resource." 27 It is possible to understand the essence of Huebner's critique of curriculum, learning, and knowledge by attending to what Heidegger states regarding the general relatedness of our thought to the sciences, which is determined by the "basic trait of the modern era," namely, "that objectmateriality which is established and maintained in power by the scientific objectification in all fields." 28

For Heidegger, this specific type of world-disclosure functions by way of objectifying and thematizing the world. As Heidegger indicates, when we approach entities in the world in terms of representing abstract scientificmathematical relationships, we reduce them to a mere present-at-hand existence, or as Heidegger states, "Being-just-present-at-hand-and-no-more,"29 and such entities have their "properties defined mathematically in 'functional concepts."'30 The implication of this for Huebner's analysis of education is expressed succinctly in Dreyfus' account of Heidegger's notion of thematizing, wherein Dreyfus concludes that one problem with this view of knowledge is that

once characteristics are no longer related to one another in a concrete, everyday, meaningful way, as aspects of a

\footnotetext{
22 Dwayne Hubner, "Curriculum as Concern for Man's Temporality," 135.

23 Ibid., 135.

24 Huebner, "New Modes of Man's Relation to Man,” 23.

25 Dwayne Huebner, "Towards a Remaking of Curriculum Language," in Heightened Consciousness, Cultural Revolution, and Curriculum Theory (Berkeley, CA: McCutchan Publishing Corporation, 1974), 38. 
thing in a particular context, the isolated properties that remain can be quantified and related by scientific laws and thus taken as evidence for theoretical entities. ${ }^{31}$

Thus, we approach entities by means of knowledge in a way that stands beyond our authentic engagement with their Being, and the so-called "bare facts" of science isolate phenomena through the "special activity of selective seeing," and thus in a duplicitous sense, "scientifically relevant 'facts' are not merely removed from their context by selective seeing; they are theoryladen, i.e., recontextualized in a new projection." 32 When thematizing entities through scientific world-disclosure, as Heidegger points out, they are freed in order that we might "determine their character objectively, which means that we free them "in such a way that they can 'throw themselves against' a pure discovering - that is, that they can become "Objects"." 33 The production, through abstracted thought, of "isolated properties with no contextual meaning" 34 provides us with a new, but "essentially meaningless, context for [present-at-hand] properties." 35 If education concerns itself primarily with a mode of learning that thematizes the content of its curriculum, and beyond, the understanding of the human being and its world, along with the things and subjects with which it deals, then it is sanctioning a form of knowing that gives rise to a limited understanding of things because it privileges a mode of disclosure that ignores the complexity and particularity of our practical and meaningful interaction with the world and those with whom we share it. As Huebner argues, when we approach the world and others "enclosed in the framework of the subject-object attitude," 36 we tend to view others as "essentially predictable, controllable," 37 as something to be "studied and known." 38 Learning grounded in abstract conceptualization, which is emphasized and favored by traditional curricular theorists and the conceptempiricists in education, removes students from the context of their involved dwelling with others and obscures, or covers over, their individuality and Being. Against this view, Huebner argues that we should not seek to encounter others "in terms of abstractions and concepts," 39 rather we should meet and commune with others through face-to-face discourse.

Inauthentic education is neither interactive nor generative, and is conceived by Huebner as acting upon the student who in turn learns, or is trained, to act upon the world because he has assimilated it in knowledge, and

${ }^{31}$ Hubert Dreyfus, Being-in-the-world: A Commentary on Heidegger's Being and Time, Division I (Cambridge, MA: MIT Press, 2001), 81

32 Ibid., 81

33 Heidegger, Being and Time, 414/363.

${ }^{34}$ Dreyfus, Being-in-the-world: A Commentary on Heidegger's Being and Time, Division I, 81.

35 Ibid., 81.

36 Dwayne Huebner, "The Task of the Curricular Theorist," in The Lure of the Transcendent: Collected Essays By Dwayne E, Huebner, 88.

${ }^{37}$ Ibid., 88.

38 Ibid.

${ }^{39}$ Ibid., 89. 
this "leads to the proposition that there is the individual and there is a world, and that the individual develops in such a way that he has power over the world or to act upon the world." 40 Huebner's critique of concept-empiricism sets up a world picture that is Cartesian in nature, or dualistic, which Heidegger refers to as the impoverished Cartesian world, which is sharply contrasted by Heidegger with the world in its ontological-existential manifestation that is linked with the worldhood of Dasein. The Cartesian "world" is meant as an "ontical concept and signifies the totality of those entities which can be present-at-hand within the world" 41 as objects situated in time-space. In this view we are subjects merely observing the world objectively and dispassionately refraining from interfering with the sense data we are receiving from the world for fear that our perceptions might lead to a distorted and inaccurate picture of reality. Legitimate knowledge is constructed from our ideas in an atomistic manner by means of establishing connections and relations between concepts to form an accurate view of (objective) reality.

To view the world exclusively in this manner misses the crucial way in which world "functions as an ontological term, and signifies the Being of those entities" 42 with which educators and students are intimately involved. Knowledge, in this view, is really an interior phenomenon occurring in the closed consciousness of the individual. Ideas (representations) in the mind appear to "picture" external reality, and when there is an agreement between our mental representations and the objective world, it is said we have knowledge. This indicates that when we know the objective world, because we have systematized facts expressed through mathematical formulae or universal laws of science, as previously stated, we act as subjects who impose our wills (through knowledge) in order to command and manipulate the world. The epistemological and ontological problem that this worldview engenders for education revolves around the model for validating truth claims that it adopts, namely, the correspondence model of truth, or epistemological model for verifying knowledge, which is based on the logic of adaequatio intellectus et rei, or "the adequation of the intellect and the thing." ${ }^{43}$

Traditional Western philosophy, and by extension educational philosophy rooted in social efficiency, erroneously claims that "the 'locus' of truth is assertion (judgment)," 44 and the "essence of truth lies in the 'agreement' of

${ }^{40}$ Hubner, "Curriculum as Concern for Man's Temporality," 136.

${ }^{41}$ Heidegger, Being and Time, 93/64.

42 Ibid.

43 Ibid., (translator's note), 257/214. The learning experiences that accompany the era of standardized, "high stakes testing" in education represent instances where knowledge (and learning) is reduced to the correspondence model of truth. The student's subjective knowledge is linked with the objective knowledge on the test in a way where it is determined to be either correct or incorrect. To assess reading comprehension or literacy based on state mandated tests embracing the Either/Or epistemological cluster, ignores any and all notions of hermeneutic and heuristic forms of meaning-making as a valid indicators of higher-level student understanding through knowledge construction and transfer.

${ }^{44}$ Ibid., 257/214. 
the judgment with the object." ${ }^{\prime 4}$ This misinterpretation of truth is prevalent today because of the influence of the metaphysics of presence, which Heidegger traces to the origins of ancient ontology, "the decisive period" when the "logos functioned as the only clue for obtaining access to that which authentically is, and for deciding the Being of such entities." 46 The notion of thematizing introduced earlier is precisely a way of "encountering entities in-the-world purely in the way they look (eidos)," 47 and looking at the world in this manner "is sometimes a definite way of taking up a direction toward something - of setting our sights toward what is [merely] present-at-hand." 48 Truth conceived only in terms of agreement overlooks the more primordial phenomenon of truth as occurrence, or happening, the moment when phenomena are first disclosed to Dasein, for as Heidegger claims, "The most primordial phenomenon of truth is first shown by the existential-ontological foundations of uncovering." ${ }^{49}$ This for Heidegger represents the Being of truth, as "Being-true," which is aletheuein, or movement into the opening of truth as aletheia - or privative expression meaning "un-concoveredness". Dasein is always "in truth" due to its disclosedness in general, its projection towards its potentiality-for-Being, which means that "Dasein can understand itself in terms of the 'world' and Others or in terms of its ownmost potentiality-for-Being." ${ }^{50}$ Heidegger claims that we are also in "untruth" due to falling, which is a component of Dasein's Being that opens it to potential deception, for even in disclosure, things can "show themselves in the mode of semblance," for there is always the possibility that what has "formally been uncovered sinks back again, hidden and disguised." 51

The notion of primordial truth as aletheia avoids Cartesian dualism as it transcends objectivist-ontology by showing that there is no interior-exterior divide between the human and its world, for truth is not conceived at a physical-spatial remove from the human's perspective, but rather a view to truth as openness to the letting be of beings and Being. We might imagine students and educators within the context of the world of their authentic learning as participating within the clearing and lighting of truth, in the open revelation of their potentiality-for-Being, or the unconcealment of beings,

${ }^{45}$ Ibid., 257/214

46 Ibid., 196/154. In "Plato's Doctrine of Truth," Heidegger details the decisive shift in Western metaphysics when truth as aletheia was subjugated to truth as "agreement" in his somewhat controversial reading of Plato's allegory of the cave. See Fried for one such critical account of Heidegger's interpretation of Plato and his metaphysical doctrine of truth: "Of course, Heidegger means by 'doctrine' (Lehre) 'that which, within what is said, remains unsaid,' rather than a self-conscious teaching of the thinker: in Plato's cave, this is the transition of truth as aletheia from unconcealment (Unverborgenheir) to the correctness of representation [...] many postmodernists who owe a debt of thinking to Heidegger have also accepted this reading of Plato [...] But such a Plato is not the only Plato." Greg Fried, "Back to the Cave: A Platonic Rejoinder to Heideggerian Postmodernism," in Heidegger and the Greeks: Interpretive Essays (Bloomington, IN: Indiana University Press, 2006), 157.

47 Ibid., 196/154.

48 Ibid., 88/61.

${ }^{49}$ Ibid., 264/221

50 Ibid., 264/221.

${ }^{51}$ Heidegger, Being and Time, 264/222. 
which is never reducible to an existent state, for it is a happening, or occurrence. Truth as unconcealedness, as primordial aletheia, "is neither an attribute of factual things in the sense of beings, nor one of propositions." 52 In the midst of truth's happening, "in the midst of beings as a whole an open place occurs, There is a clearing, a lighting," 53 and by means of this open clearing aletheia "grants and guarantees to us humans a passage to those beings that we ourselves are not, and access to the being that we are ourselves are." 54 Truth as aletheia in fact makes possible truth as agreement, it is the primordial "condition of the possibility" 55 of truth as correspondence. The understanding of truth as an original event presupposes that we are always already situated in the world, immersed within our existence. This dramatically influences the manner in which we understand and discourse about the world and others. To let the world be seen in its "unhiddenness" means that we let the world come to presence in the mode of its own self-showing, in ways that are meaningful to us.

Huebner's critique of learning in social efficiency ideology is linked directly to Heidegger's interpretation of the Cartesian world of objects, for if we are perceiving the classroom in such impoverished terms, focusing only on the objective features of the things we deal with, their present-at-hand attributes, their abiding presence, educators are missing the fact that things and people always reveal themselves in a larger context, within a context of meaningful relations, which cannot be reduced to the knowledge of things available to us by way of themativing the world. This represents a persistent problem for educators, namely, the loss of meaningful educational experiences for students: To focus on the 'facts' of our educational subject-matter, those aspects of curriculum that can be efficiently mastered and demonstrated through rigorous forms of examination, pays no heed to bow the content is meaningful to the student's Being or her world. The notion of authentic meaning in constructivist terms will be explored in the final section of the essay, for it underlies Huebner's understanding of authentic learning, which is grounded in the human being's authentic relation to its world. As Huebner suggests:

The individual is not separated from the world, or apart from it - he is a part of it [...] if a curricular language can be developed so that the educator looks at the individual or the situation together, not separately, then his powers of curricular design and educational responsibility might be increased. ${ }^{56}$

52 Martin Heidegger, Poetry, Language, Thought, trans. by A. Hofstadter (London: Harper \& Row, 1971), 54.

${ }^{53}$ Ibid., 54

${ }^{54}$ Ibid., 53.

55 Dreyfus, Being-in-the-world: A Commentary on Heidegger's Being and Time, Division I, 199

${ }^{56}$ Huebner, "Curriculum as Concern for Man's Temporality," 136. 


\section{The Potential Implication of Authentic Learning for Education}

Inauthentic learning is concerned with knowledge that is both instrumental and of a distinct variety, namely, logical-rational-scientific, and education that lives in the shadow of positivism runs the ever-present risk of degenerating into a form of curriculum-making where technicalization and byperrationalization dominate. The former focuses on the utility of our knowledge at the exclusion of the concern for meanings, for why we do things and why they are meaningful to us; the latter, favors the application of reason alone to our analyses of the world at the exclusion of the concern for the emotional and spiritual dimensions of our Being. Education in this view is reduced to students navigating the world of present-at-hand entities with the goal of mastering and controlling the environment and the things therein by means of the power they gain through acquiring objective knowledge. Not that educators should avoid experiences that focus on the empirically verifiable aspects of reality, but this form of learning-knowledge should not be privileged above all other ways of knowing, understanding, and intuiting the crucial dimensions of the student's Being. Hermeneutic interpretive meaning-making should be an integral part of the learning experience in the classroom and educators should demonstrate a genuine concern for the general intangible aspects of the learner's Being-in-the-world, which cannot be quantifiably measured or validated by means of the traditional epistemological model grounded in the differentiation between a priori-analytic and a posteriori-synthetic.

Inauthentic learning situates the source of knowledge outside of the learner in the objective world. The types of inauthentic learning experiences that accompany the era of standardized, or "high-stakes testing," in education are instances where objective knowledge is situated at a remove from the student, is then imparted to the student, for which the student is then responsible for identifying and recognizing on the test. If the student's (subjective) knowledge is linked correctly with the objective knowledge on the test, she demonstrates knowledge. To assess reading comprehension or contribute to the determination of literacy based on a test privileging the Either/Or epistemological cluster (by means of employing the correspondence model of truth), ignores constructivist knowledge, or understanding, emerging from hermeneutic interpretation and meaning-making as strong indicators of higher-level understanding. This misses the more primordial aspects of learning through interpretive activities as process of uncovering Being, which is associated with the primordial revelation of truth, or the making-present of truth, as aletheia.

Authentic education organizes learning experiences so as to encourage students to inhabit and interact with the world of the classroom in terms of being "open" to the world they encounter within the various activities that comprise their learning experience. Students should be encouraged to allow things to come to presence in truth, in the very light of their own self-showing, and most importantly, in ways that matter to them, in ways that have meaning 
for their Being. Educators should resolutely pursue the formation of students by letting them be, as it were, allowing their unique possibilities for Being to shine forth. The essence of truth, and hence knowledge and understanding, should not be thought of as residing in propositions, formulae, standardized tests, or other such vehicles for packaging, transmitting, and assessing the validity of truth, all of which express the correspondence between the internal representation (idea) of the subject and the existing (real) objective state-ofaffairs. Rather the essential way in which we are "in-truth" occurs through disclosure, as we are "there" in moments of authentic discovery, which is the occurrence of both students and educators actively uncovering their authentic possibilities as related to their Being within the authentic context of navigating solutions to the problems they encounter.

\section{Huebner, Heidegger, and Ecstatic Temporality}

There is yet a third aspect of Huebner's critique of education emerging from his focus on objectivist-ontology and the epistemological reliance on logical-rational-scientific knowledge as the gold standard for learning, and that is his concern with transcending the inauthentic notion of temporality that accompanies these aforementioned educational philosophies, especially prevalent within the erroneous view wherein knowledge is thought to map both space and time. As Huebner points out, "Man abstracts from the processes of life as if his only meanings were in the spatial world not necessarily in the temporal," 57 and if this crucial issue is confused or ignored, namely, the undeniable spatial characteristics of knowledge, the educator is in danger of viewing and interacting with the world "as if it were relatively stable in time," 58 i.e., in an a-temporal and a-historical manner. Due to the misunderstanding of authentic temporality, contemporary curriculum philosophy erroneously conflates education theory, which is practical, with scientific theory, which describes, explains, and predicts, and so researchers wrongly view educational programs as having a direct, observable, and predictable application within classrooms. In distinction to this view, authentic educational theory attempts to suggest what we ought to be doing in the classroom, and as opposed to objective and disinterested, according to Huebner, it is unabashedly subjective, value-laden, and emancipatory. Huebner, taking up Heidegger's interpretation of "ecstatic temporality," claims that we need to embrace the view of time in which we embody our past, as heritage, and stand out in projection toward an indeterminate future, which returns to meet us in the authentic present when our authentic possibilities are opened for appropriation. Huebner's authentic understanding of time in its relation to curriculum studies challenges the vision, design, and implementation of the curriculum in contemporary education, which is erroneously conceived in terms of a linear understanding of time.

\footnotetext{
${ }^{57}$ Huebner, "Towards a Remaking of Curriculum Language," 39.

${ }^{58}$ Ibid., 39.
} 
Huebner links temporality with historicality in terms of Heidegger's understanding of Dasein's authentic comportment in the moment of vision, and thus a brief overview of the process of Dasein's temporalizing, in addition to a few words about time as conceived by Heidegger, will assist the understanding of Huebner's individual-world dialectic, which provides the design of the classroom's temporal-historical environment. Huebner's strives to overcome the erroneous conception of the student as an ahistorical subject situated within a linear conception of time conceived as a series of "now" points, unfolding in three the distinct moments of past, present and future. In this view of time, as Heidegger argues, past and future are subordinated to the present, the "nun [now] is the metron [measure] of past and future,"59 and as a result "time is always interpreted as present, past is interpreted as no longer present, future as independent not-yet-present." 60 Importantly, this leads to an inauthentic view of our historical evolution and development, for in it the dynamic unfolding of our authentic historizing is reduced to an inauthentic view wherein history is conceived in terms of "historiography," or the scientific discipline that studies past events, cultures, and their artifacts.

According to Heidegger, history, as "historiography," is concerned with those things once present, now forever gone, and so the past is conceived as belonging "irretrievably to another earlier time." 61 This idea is linked to the understanding of human history in terms of a series of irretrievable events or moments. This engenders an inauthentic understanding of the significance of the past in relation to Dasein's future and present, and arises as a result of its falling and its absorption in the "They-self" and the everyday ways of understanding its existence, and "allows what has passed to be only in the past, which lets it freeze in the finality of [its] rigor mortis." 62 The interpretation of time as a linear phenomenon covers over the ontological-existential significance of Dasein's death, birth, and heritage, as thrown having-been - it's authentic life. According to Heidegger, history happens in praxis in terms of Dasein's historicality, which is the living event of Daein's freedom in relation to its past in the projection of its authentic possibilities, which arise from its past as heritage. Historicality, according to Huebner, as it relates specifically to curriculum development in education, is associated with practice, and in his view,

practice as human event suggests the essentially temporal nature of man and points to the linkage of biography to history as a major educational concern. Curriculuralists have ignored such questions of destiny, finitude, and the

59 Martin Heidegger, The Concept of Time, trans. by William McNeill (Malden, MA: Blackwell Publishing. 1992), 17e.

${ }^{60} \mathrm{Ibid} ., 17 \mathrm{e}$.

${ }^{61}$ Heidegger, Being and Time, 430/378.

62 Martin Heidegger, What is Called Thinking?, trans. by John Gray (New York, NY: Harper \& Row, 1968), 103. 
meaning of morality of the influence of one human being on another. 63

Huebner argues that the traditionalists and concept-empiricists in curriculum theory are either concerned with establishing goals, purposes, and objectives, which orient learning exclusively toward the future, with the specific task of determining the student's "future behavior," or they are locked within the static moment of the present, which leads to the failure to understand the potential for change and to realize that "human life is never fixed but is always emergent as the past and future become horizons of the present." 64 Heidegger traces the loss of Dasein's authentic temporal Being to the inauthentic, everyday interpretation of existence in which Dasein "temporalizes itself in the mode of making-present," 65 and by locating itself in the hypostatized moment of the present (or "now"), Dasein "loses his time"6r because it fails to await the approach of the authentic future from out of its past, heritage, or baving-been. This also represents the loss of Being, which emerges from a misunderstanding of Being as being present, i.e., the event of Being is conceived as "pure presence, that is, the presence that persists, the abiding present, the steadily standing 'now'." 67 This inauthentic interpretation of Being is linked inextricably with temporality, and it erroneously views beings as standing outside of time, as independent of time, and subsequently, this view of time "sees time in the sense of a passing away." 68 Rather, an authentic temporal existence, states Huebner, remaining close to Heidegger's notion of ecstatic temporality as it is linked with historicality, requires "inspection of the past (or the present as the already-past)," ${ }^{9}$ along with the "identification of forms of existence or aspects of life considered worthy of maintenance, transmission, or necessary for evolution; and the projection of these valued forms into the future." 70

Huebner expresses succinctly the inauthentic interpretation of time when stating the following: "Man, has constructed his scientific view of time as something objective and beyond himself, in which he lives." 71 Such a view is opposed to the manner in which Heidegger views Dasein's authentic relationship to time, for as he states, "Dasein conceived in its most extreme possibility of Being is time itself and not in time." 72 Time is not objective, for the duration or length of time cannot be measured scientifically by way of mathematical symbols, for time has no length. While mathematical-scientific knowledge accurately measures the medium of space, it is powerless to calculate, gauge, and represent the non-spatial medium of time, with its

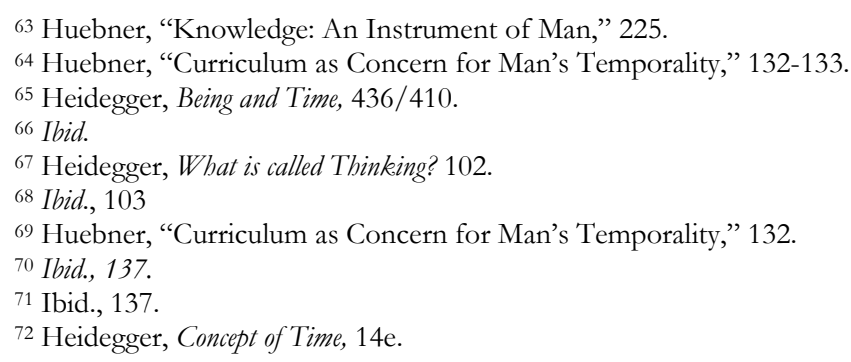


dynamic flux and flow. The future does not rush toward us as we stand in the present moment, only to disappear forever into the irretrievable void of the past. In addition, time is not linear, and neither the wall-cock nor wristwatch properly presents time, and according to Heidegger, by treating time as a quantitative phenomenon, measurable in length, in its extension, the clock attempts to show us "what" time is, but misses the more substantial ontological-existential matter of how time is, which is to say, the way in which we enact our time when living as temporal, existential beings.

Our humanity, or ontological self-hood, is inextricably grounded in ecstatic temporality, wherein past, present, and future are united, indivisible, perpetually working in concert within the moment of our present. This moment of the present is the authentic moment of vision, i.e., the revelation of truth and subsequent appropriation of our authentic Being-in-theworld. It is not "present" in terms of a point that is situated between future and past. It is the moment in which the world, beings, and entities reveal themselves in ways that matter within the "there," or disclosedness, of Dasein. As Heidegger states, this moment of vision is possible due to the convergence of past and future, and this suggests that the past circles round to meet us, "the coming [Kunft] in which Dasein, in its ownmost potentiality-for-being, comes toward itself," 73 from out of the indeterminate future, and thus the past is never legitimately gone. The fact that we have a past cannot be overlooked or skirted, as it represents our being thrown into the world in a specific and unique manner. However, the past acquires meaning only when we authentically project it into the future, and when "authentically futural, Dasein is authentically as 'having-been,' as its own thrown past."'74

Authenticity represents our "most extreme possibility of Being," 75 it is a life in praxis, a temporal process of taking over our existence through interpretive decision-making, whereby we legitimize our thrown-past (baving-been) in the service of making (and re-making) our future Being. Dasein's authentic Selfhood is only to be found in the "authentic-potentiality-for-being-one's-self - that is to say, in the authenticity of Dasein's Being as care." 76 For Heidegger, the "primordial unity of the structure of care lies in temporality" 77 and this relates to the Being of Dasein as "Care," which embodies the three moments, or horizons, of ecstatic temporality: (1) we are always out-ahead-of-ourselves in the projection of a future, (2) we are always along side both things and Others in the world, and (3) we are always already in the world as a thrown, living being, as someone with a past, a history and heritage. When considering such a model of temporality, of which "clock time" is merely derivative, it is crucial to acknowledge that the past, which constitutes our living history and heritage, is sewn into the very fabric of our Being. The past is continually at work

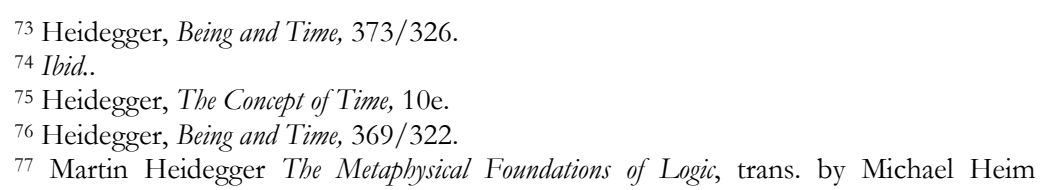


influencing and shaping the moment of vision through its ever-attendant presence. The past serves as the source of our historical life and future; it allows us to redefine our existence by making choices on the possibilities that emerge from our heritage, which is at once the historical ground of our existence.

It is possible to grasp ecstatic temporality in the following manner: In the moment of resolute openness (Entschlossenheit), the mood of Angst individuates Dasein for its death and ownmost possibilities for Being, opening what Heidegger terms, the "Situation," or the authentic way of "Being-there". Conceived as a temporal phenomenon, the Situation is Dasein's moment of vision or instant of authenticity. "In the instant as an ecstases," writes Heidegger, "the existent Dasein is carried away, as resolved, into the factically determined possibilities, circumstances, contingencies of the situation of action." 78 This is the authentic present of ecstatic temporality, when Dasein, accessible and free, projects itself into its possibilities within the factical and distinct circumstances of its own unique life. Such an authentic resolute openness to worldly encounters is only possible because Dasein, as a temporal being that temporalizes, is at once its future, past, and present as thrown-projecting Being-in-the-world.

The present, which is held within authentic temporality, is the sustaining form of Dasein's authentic choices, representing the "resolute rapture with which Dasein is carried away to whatever possibilities and circumstances are encountered in the Situation as possible objects of concern." 79 The authentic temporalizing of Dasein occurs as it projects its finite possibilities, which initiates a forward movement towards itself as resolute Being-towards-death in its ownmost potentiality-for-Being, and this movement secures a "repetition," or authentic retrieval, of Dasein's having-been. In coming to or toward itself, from out of its indeterminate future, as engendered by its own past, Dasein discloses the meaning of authentic Being within the instant of the present, or moment of vision (Augenblick), ${ }^{80}$ of the Situation. This ecstatic temporal process represents the letting be of Being, which represents the authentic truth of existence. Thus, when Dasein exists authentically, it experiences the world in its basic "uconcealment" - allowing that which shows itself from itself to be seen - now not disclosing beings as present-at-hand entities, or objects, but the phenomenon of world as such, the worldhood of the world, i.e., the overarching matrix of meaning and purpose structuring Dasein's being-inthe-world, which understanding and interpretation have in great part made possible for Dasein. ${ }^{81}$ The process of temporalizing, as described above, will be

\footnotetext{
78 Ibid., 297.

${ }^{79}$ Heidegger, The Metaphysical Foundations of Logic, 287.

${ }^{80}$ McNeill translates Augenblick as "the glance of the eye," and prefers this translation to moment, moment of vision, or enpresenting. He writes that the German employed by Heidegger "carries both a visual and temporal sense, conveying the momentary 'character' of seeing." In line with Huebner's rendering of Augenblick, I have retained, "moment of vision." William McNeill, The Glance of the Eye: Heidegger, Aristotle, and the Ends of Theory (Albany, NY: State University of New York Press, 2000), ixx.

${ }^{81}$ Huebner describes the process of temporalizing in similar, albeit not identical terms, when stating the following: "The past is finding himself already thrown-into-a-world. It is
} 
further developed as an authentic historical occurrence in the final section of the essay when analyzing Huebner's individual-world dialectic.

\section{The Potential Implication of Ecstatic Temporality for Education}

Due to an inauthentic understanding of time, educators orient the curriculum and the learning experience contained therein toward the future, which is conceived as knowable and determinate, creating an education program wherein goals, aims, and purposes are posited in advance of the authentic experience of education in its practical enactment, and toward which students are then led. Such a strict product-process model for curriculum assumes that it can specify the student's future behavior because it is determinate and thus predictable. In many instances, the student's authentic possibilities are defined in advance by educational professionals residing at an external and temporal remove from the authentic unfolding of the student's Being in the processes of learning. For example, private foundations (Carnegie Corporation) and accrediting testing agencies (ETS - Education Testing Service), situated at a remove from the classroom, represent professional organizations that are in charge of establishing the standards criteria for learning within educational institutions. This expression of the inauthentic understanding of time covers over and obscures the student's genuine potentiality-for-Being. Whereas the authentic understanding of temporality makes possible moments of resolute openness wherein students choose to enact their authentic possibilities within a learning environment facilitating the autonomous and self-directed revelation and appropriation of their authentic possibilities for the enactment of their Being.

Due to the inauthentic understanding of time, it is also possible for educators to remain locked within a view to the present, which presupposes an understanding of time where the past is gone and irretrievable and the future has not yet arrived. This represents a form of presentism in education, i.e., the current conception and inception of educational systems, institutions, philosophies, and theories are conceived as existing "in time," and since they

having-been that makes possible the projection of his potentiality. The present is the moment of vision where Dasein, finding itself thrown into a situation (the past), projects its on potentiality for being. Human life is not futural (my emphasis); nor is it past, but, rather, a present made up of a past and future brought into the moment." It must be noted that while Huebner certainly remains very close to Heidegger's original interpretation of ecstatic temporality, the remark stating that we are not futural beings is inconsistent with what Heidegger indicates regarding the primacy of the future ecstases in the care-structure and the authentic temporalizing of Dasein, for the "future (ecstases) has a priority in the ecstatical unity of primordial and authentic temporality." Heidegger claims that although all modes of temporality are equiprimordial, their "modes of temporalizing are different," and to understand "primordial and authentic temporality" we must note that it "temoralizes itself in terms of the authentic future and in such a way that in having been futurally, it first of all awakens the Present. The primary phenomenon of primordial and authentic temporality is the future." Heidegger, Being and Time, 378/329. 
are viewed only through the lens of the present, as making-present, they assume eternal, indelible, and hypostatic characteristics, making the possibility for authentic educational reform not only a daunting task, but a fatalistic impossibility. This view of time remains blind to the crucial role that the past plays, as heritage, in the historizing process of the student, which represents her unique potentiality-for-Being as related her living past (and not merely a historical past), which is always alive with the potential for growth and transcendence, and is taken up into the authentic leaning experience, which is the convergence of past and future in the moment of vision.

There are also models for curriculum-making that are situated in the present while demonstrating an unquestioned reverence for the past and its educational traditions, where change is viewed in terms of superficial improvements to a grounding, foundational form that essentially remains unchallenged and unchanged. These philosophies of education have firm roots in the thought of the past and present. When conceiving an essential education for students, in terms of a perennial or permanent curriculum, they are really imitating the past, aping the past, recreating the past in the present without attempting to reassess or reinterpret it in light of the students' needs and wants, in terms of their unique and futural potential-for-Being. This inauthentic view of education embraces the status quo in curriculum, its content, pedagogical methodology, and assessment strategies, and in no way represents the emancipatory move beyond the current manner in which students, education, and society are conceived.

\section{Authentic Education and the Individual-World Dialectic: Navigating the World as Temporal-Historical Being-in-the- World as Being-with Others}

Huebner's concern with temporality is more complex than simply the issue of educators, who are designing and implementing curriculum, demonstrating a concern for the unfolding of time, or taking an interest in history as a dynamic process, for these are concerns for historicist critique, and this, of course, is not what Huebner is engaged in. Rather, on a primordial and ontological level, Huebner is concerned with how we enact our authentic existence in terms of the authentic unfolding of our historical being, and beyond, he is concerned with how thinking education might be enhanced when informed by the types of ontological-existential issues that are bound up with the authentic enactment of students'/educators' Being-in-the-world. According to Huebner, "Curricular practice is not simply the concern for the constellation of the educative environment," it is the "concern for the human events that occur within that environment." 82 To fully grasp the significance of the individual-world dialectic, Huebner's notion of educational "practice" must be elucidated in terms of practical human activity, which dynamically embodies the "essential temporal nature of man and points to the linkage of biography to

${ }^{82}$ Huebner, "Knowledge as an Instrument of Man," 225. 
history as a major educational concern." 83 Ultimately, it is Huebner's notion of the individual-world dialectic that serves as the organizing philosophical force for reconceived curriculum design as inspired by thinking ecstatic temporality in relation to education. Analyzing the individual-world dialectic will reveal the kinship between Huebner's philosophy of education and Heidegger's thinking on Dasein's authentic historicality. Unpacking the following quotation by Huebner reveals that Huebner's individual-world dialectic springs from the founding ground of Heidegger's thinking on the basic constitution of historicality, which includes, as I show, the notions of heritage, fate, and destiny as related to our authentic historizing as communal beings.

The springs or sources of temporality do not reside in the individual, but in conjunction between the individual and other individuals, their material objects, and other ways of thinking as they are objectified in symbol and operation. Furthermore these springs or sources, although again not residing in society, are nevertheless unveiled, maintained, and protected by society. Thus man shapes the world, but the world also shapes man. This is the dialectic process in which cause is effect, and effect is cause. The world calls forth new responses from the individual, who in turn calls forth new responses from the world. ${ }^{84}$

I begin the analysis by clarifying Huebner's notion of authentic learning, which as opposed to learning grounded in abstraction and generalization is a more primordial form of knowledge, or better, understanding, through which students and educators interpret the world in meaningful ways. Authentic learning for both Huebner and Heidegger represents acts of understanding, and this form of insight, which is refined through interpretation, will provide insight into the relational character of human existence in terms of Huebner's understanding of the individual-world dialectic, which is at once the temporal-historical happening of our Being, comprising the totality of the environmental design of the curriculum. For Heidegger, understanding is know-how, by means of which we navigate our world, and projection, or the manner in which Dasein, in its understanding, is always already-out-ahead (ecstatic 'standing-out') of itself in its futural projection. Dreyfus explains that understanding as know-how "makes possible skillful coping," 85 and "relates some activities as doable, as making sense, and others as not, or better, it does not recognize these other possibilities as possibilities at all." 86 Understanding is directed toward accomplishing one or another task or

83 Ibid., 225.

${ }^{84}$ Huebner, "Curriculum as a Concern for Man's Temporality," 138.

85 Dreyfus, Being-in-the-world: A Commentary on Heidegger's Being and Time, Division I, 184185

86 Ibid., 184-185. 
activity, "coping with the available proceeds by pressing into possibilities," 87 and the manner in which Dasein's "coping is organized by a for-the-sake-ofwhich,"88 and this for Heidegger is projection. Projection, it must be noted, is always bound up with the entities with which Dasein deals, which of course includes others, in terms of understanding and possibilities.

As stated, 'know-how' as understanding for Huebner, is linked with doing something with our understanding, but as opposed to the functional efficacy of either pragmatic or scientific knowledge of the world, Huebner views understanding as akin to existential thought, meditative thought, where doing something with understanding might include "new exploring, more satisfying expression, deeper and more meaningful encounters with others, greater awareness of what and who [we are], and more ability to build and transform the world." 89 Understanding, for both Huebner and Heidegger, is therefore sharply contrasted with knowing as thematizing, for understanding "is not cognition at all in the sense of grasping something thematically." 90 Rather, it is linked to the "Being of the "there' [of Dasein's disclosedness]," and is "primordially existential, it means to be projecting towards a potentiality-forBeing for the sake of which Dasein exists." 91 Through understanding Dasein projects its for-the-sake-of-which, when it is open to futural possibilities that are on the approach, which acquire meaning only in relation to the significance of the structure of the for-the-sake-of-which, the towards-this, and the in-order-to of the authentic "worldhood of its current world." 92 However, this for-the-sake-of-which is not a determinative goal or end that Dasein posits in advance of its activities, rather it is a way of understanding the meaning-schemata of Dasein's Being-inthe-world, where it "throws before itself the possibility as possibility and lets it be as such." 93 The system of relations Heidegger describes pertains to Dasein's Being-in-the-world as a whole. As related specifically to the process of education envisioned by Huebner, the for-the-sake-of-which of learning represents the groundless, or shifting, ground of the authentic curriculum, where educational aims for student achievement are imminent within and emerge from the unfolding of the learning. It must be noted that the for-the-sake-of-which of education functions in terms of being projected within a community of learners, for no student can ever have self-knowledge or authentic knowledge of her world at a remove from interpersonal contact. Heidegger is clear on this matter when writing, "The world of Dasein is a world-with [Mitwelt]. Being-in is Being-with-others. Their Being-in-themselves-within-the-world is Dasein with [Mitdasein]." 94

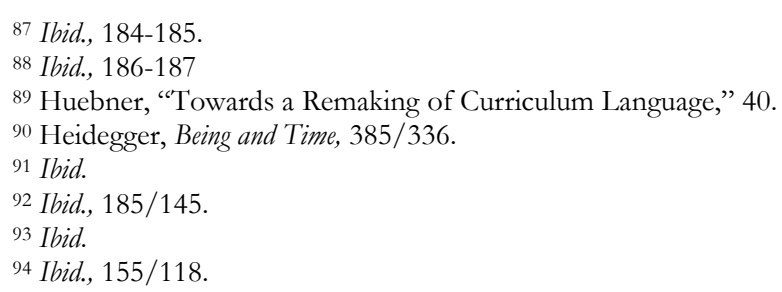


Interpretation for Heidegger, works to clarify what is ambiguously given in understanding, and is never a "presuppositionless apprehending" of things, rather all of our interpretations begin as something, in terms of Dasein's fore-having, fore-sight, and for-conception. ${ }^{95}$ We approach the things themselves, guided in the first instance by both their uniqueness as well as a preconception of what they might be, seeking to clarify our initial veiled and unclear conceptions of them in order to eventually deepen and solidify our understanding of them. This is accomplished through hermeneutic interpretation, where our pre-understanding of things, as it were, allows us to step into the circle, or spiral, of interpretation. When things, in relation to our Being are understood, "we say that they have meaning [Sinn]." 96 As we work to clarify our understanding through interpretation we produce or construct meaning, and as Heidegger claims, meaning represents "the 'upon which' of a projection in terms of which something becomes interrogated as something; it gets its structure from a fore-having, fore-sight, and fore-conception." 97 This form of making-meaning is precisely what Huebner has in mind when he talks of hermeneutic activity as central to the dialectic between individuals, their history, and world in terms of a confrontation, which he describes as the rhythmic continuity and change of the individual's understanding and involvement with her world. For Huebner, hermeneutical activity is a communal art, a "way of getting at pedagogical method and interpreting what goes on in the classroom or other educational places." 98 Interpretation, as an ongoing process, is always at work in education, and "whether by asking questions, establishing written assignments, reading to the child, or pronouncing words for him," educators are "introducing him to traditions of interpretations." 99

Huebner claims that the educational environment embodying "the dialectical forms valued by society would require three aspects or components." 100 It is possible to understand the three aspects of the individualworld dialectic transpiring within education, guided and directed by the design of the curriculum, in terms of Heidegger's understanding of authentic historicality

${ }^{95}$ Ibid., 191-192/150.

96 Ibid., 192/151.

${ }^{97} \mathrm{Ibid}$.

98 Huebner, "Towards a Remaking of Curriculum Language," 47.

99 Ibid., 48. Although an analogy can be drawn between all forms of student learning and the interpretive process, for example, Huebner talks of the "interpretation" involved in the phonetic exercises of children during reading instruction, this would not amount to an instance of authentic hermeneutic interpretation, for as Huebner makes explicit, the term "hermeneutic" should not be substituted for "the words teaching method," as there are a variety of pedagogical methods at work within an authentic curriculum. In addition, it might be argued that Huebner views hermeneutic interpretation in terms other than a formal methodology and rather as a primordial way in which we are in the world, representative of our capacity and capability to search out meaning and form an understanding of our lives. However, Huebner is clear that it is within the context of hermeneutic interpretation alone that humans authentically come to know themselves, each other, and are empowered through discourse to understand and change the world and society of which they are a part

100 Huebner. "Curriculum as Concern for Man's Temporality," 139. 
and the notions of heritage, fate, and destiny, the invariant structures that ground Dasein's historicizing, all of which correspond to the human's temporal Being as "Care". Authentic education shows a concern for both the evolution of the human being as well as the community, and Huebner envisions education as the "manifestation of the historical process, meshing the unfolding biography of the individual within the unfolding history of his society." 101 Huebner claims that the ideal learning environment represents the unfolding of human temporality as historicality through hermeneutic interpretation, and is an environment that (1) calls forth a response from the student, (2) is reactive, and (3) makes possible authentic moments of vision, "when the student and/or those responsible him, project his potentiality-for-Being into the present, thus tying together the future and the past into the present."102 The educative process conceived by Huebner should be understood in terms of Heidegger's thinking on Dasein's resolute historical existence, where "resoluteness implies handing oneself down by anticipation to the 'there' of the moment of vision; and this handing down we call 'fate'. This is also the ground for destiny, by which we understand Dasein's historizing in Being-with Others." 103

The curriculum as conceived by Huebner represents the authentic dwelling of students and educators in the midst of a living tradition, wherein they consider questions about what is valued, what traditions should be preserved or altered, what should remain as part of the collective memory now and in the future. This is not simply about teaching students about our past and its traditions, not simply about deciding what knowledge from our past is most valuable and therefore should be learned and passed along. Rather, authentic education represents a collective decision about what aspects of our tradition, or collective ethos, are in fact worthy to be taken up in "repetition" and projected, as authentic possibility, into the future as destiny. In order to call forth responses from students the living aspects of our heritage must be embraced, they must be recognized as forming our authentic past, for in such a view our heritage alone is worthy enough to demand and warrant a response, a rejoinder that takes seriously the responsibility we have to our own unique potentiality-for-Being. It is interesting to note that in Heidegger's analysis of authenticity, in terms of resolute, individuated Dasein's Being-towards-death, he refrains from including a discussion about the explicit factical possibilities that are made available to the resolute Dasein for comportment. In fact, Heidegger stresses that such an investigation "excludes even the existential projection of the factical possibilities of existence," and so he considers where "in general Dasein can draw those possibilities upon which it factically projects itself,"104 for projecting itself on the possibility of death alone as possibility, "gives only the totality and authenticity of one's resoluteness." 105 It is in fact from the past, as heritage, that Dasein's factical possibilities, in terms of its

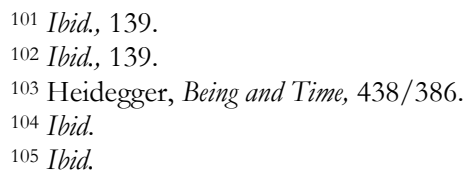


potentiality-for-Being, first arise, representing the so-called "content" of authentic existence to which form is provided by Dasein through the autonomous enactment of its historical Being.

The resoluteness in which Dasein comes back to itself, discloses current factical possibilities of authentic existing, and discloses them in terms of the beritage which that resoluteness, as thrown, takes over [...] if everything 'good' is a heritage, and the character of 'goodness' lies in making authentic existence possible, then the handing down of a heritage constitutes itself in resoluteness. ${ }^{106}$

Heritage, as authentic thrown having-been, is what demands a rejoinder from Dasein, and Huebner refers to heritage as the students' "collective wealth," and represent speech patterns, forms of dialogue, language of the curriculum, structural forms of various disciplines, and our collective ethos, the habituated behaviors and beliefs of a historical culture, along with "the social customs shaping interacting patterns, and the man-made things that make up much of the man's world."107 Within these aspects of heritage "we find the stuff for our hermeneutic and world-building arts"108 and they inform the forehaving, fore-sight, and fore-conception that the student brings to the context of interpretation, wherein memories of their collective existence are set within a "caring collectivity in which individuals share memories and intentions,"109 and through the process of learning, "form a bridge between self and other; a linkage among past, present, and future; the vehicle by which individuals, in community, arrive at mutual understanding in the conduct of their public affairs." 110 The past becomes the means by which students project their own potentiality-for-Being as historical, and the educational environment must be designed with the understanding that the past is always present as the basis for our futural projection. This relates to what Heidegger claims about heritage and "the possibility that Dasein might choose its hero" 111 from out of the myriad of historical possibilities that the past has made available for potential appropriation. "For this," as Inwood writes, "Dasein must return to the past, perhaps to its own birth, but more likely beyond. There are great philosophers, generals, statesmen, artists, saints, and lovers whose deeds and works are part of Dasein's heritage."'112

In addition to calling forth a response from students, the educational environment "must be reactive, or else the student must question it so that it

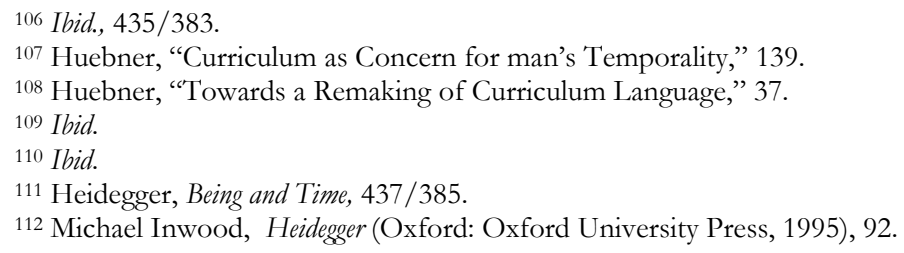


responds to him."113 This relates directly to the unique possibilities that manifest in a way in which our "accidental" and "provisional" possibilities are "driven out" and our existence is pushed into its "finitude," and at that instant, we are "snatched back from the endless multiplicity of possibilities which offer themselves as closest," and this brings us "into the simplicity of [our] fate (Schicksal)."114 Dasein is aware of enacting only a limited number of possibilities, and it understands that these possibilities are approaching from out of the past as its living heritage. Fate, according to Heidegger, is determinative of Dasein's futural projection and the authentically "historical" moment of vision. Fate is the manner in which Dasein opens the present, enacting its existence temporally as it experiences its freedom towards its authentic possibilities, and freedom arises from the limitations and finitude of its existence, and is in turn defined by the burden of its heritage. Fate is the how of comportment, the authentic enactment of Dasein's existence as thrownprojection, as it draws possibilities from its heritage and in a decisive manner chooses among the possibilities afforded by its past, and this is the reactive aspect of the learning space. "Fate is the authentic resoluteness in which Dasein holds itself free for death, in a possibility it has inherited and yet chosen." 115 This is what Heidegger means by stating that our finite possibilities are always drawn from heritage, and in terms of Huebner's understanding of the individual-world dialectic, it is the recognition that this reactive aspect of the learning experience happens in terms of the reciprocal counter-striving between the student and her world, for as indicated earlier by Huebner, the student shapes the world and the world in turn shapes the student. This occurs only within a curriculum design acknowledging temporality and historicality, because the reactive aspect of authentic education hinges on the emergence of the "past as part of the valued past brought into the present of the student."116

Educators must facilitate the emergence and occurrence of moments of vision, wherein student's authentic possibilities for their Being manifest; they

\footnotetext{
113 Huebner, "Curriculum as Concern for man's Temporality," 139.

114 Heidegger, Being and Time, 384/335.

115 Ibid., 435/385.

116 Huebner, "Curriculum as Concern for Man's Temporality," 139. It must be further
} stressed that Huebner's notion of "reactive" runs contrary to the notion of "reactive" found in behaviorism and concept-empiricism, and this might be elucidated by attending to Grumet's distinction between the behaviorist conception of the human subject and the subject as conceived by phenomenology and existentialism. The subject is not merely reactive to external stimuli, which would reduce the human to a "tabula rasa upon which the world makes its marks, a template of social conditioning." The notion of reactive in phenomenological philosophies of education denotes "discourse," or the confrontational dialogue between individual and world wherein the human is equipped to freely "interpret, repudiate, or reaffirm experience," i.e., actively construct menaing. As Grumet argues, to delete discourse from the educational experience would reduce "learning to a series of reactive, conditioned behaviors best described as training," and although this description is affirmed by the behaviorists, "it is rejected by existentialist [and phenomenologal] philosophies in their acknowledgement of commitment and human freedom." Madeleine Grumet, "Existential and Phenomenological Foundations of Autobiographical Methods, in Understanding curriculum as phenomenological and deconstructed text (New York, NY: Teacher's College Press, 1992), 23. 
must work with students in order to ready them, in moments of resolute openness, to enact their authentic possibilities, moments where the indeterminate future approaches to converge with their past, which is carried into, thereby breaking open, the authentic present of the Situation, "thus tying together the future and past in the present."117 In light of the ground covered, it is possible to conclude that an authentic education as conceived by Huebner is one in which the design of the curriculum fosters the individual-world dialectic, which unfolds by means of hermeneutic meaning-making, informed by the student's authentic potential-for-Being. Authentic education makes possible the emergence of the student's authentic possibilities for establishing her historical grounding as destiny in the moment of vision; Through appropriation she enacts her authentic way of being-in-the-world as Being-with Others. The classroom is never merely a collection of individual and disconnected fates, as it is guided in advance by the fact that human existence is authentically communal. Rather, the classroom is a place of dwelling wherein "our fates have already been guided in advance, in our Being with one another in the same world and in our resoluteness for definite possibilities."118 The design of the classroom environment within an authentic view to education sets up the solicitous context

where adults seek to influence the young, where the young influence the adults, a place where the past is presently used, interpreted, rethought, and reworked; a place of not submitting to someone else's powers and accustomed ways but of negotiating for power in the maintaining and reforming of the public world. ${ }^{119}$

Destiny, within the individual-world dialectic, must be conceived as the ecumenical pursuit of authentic learning where the classroom represents an originary community, wherein we dwell in learning with others. In this community, students are beholden to the processes of education, as "each individual is bound up in advance to something that binds and determines each individual by exceeding them," 120 and this occurs within an atmosphere of solicitous care that unfolds through the process of interpretive meaning-making. Here, student and educator care for the communal archive of knowledge that is developing within various learning experiences, which is bound up with care for the both the student's store of knowledge and unique cultural heritage as related to the her own unique possibility for existence, which grows and evolves within the flux, flow, and rhythmic dynamic of the unfolding of education as a temporal-historical phenomenon. When learning authentically with others, we share a like-minded sense of care for our common fate as

117 Ibid., 139.

118 Heidegger, Being and Time, 436/385.

119 Huebner, "Towards a Remaking of a Curriculum Language," 52.

120 Martin Heidegger, Holderlin's Hymns: 'Germania and The Rhine, trans., William McNeill (Bloomington, IN: Indiana University Press, 2004), 74. 
learners. Destiny is the authentic enactment of our potentiality-for-Being as historical, when through communication and struggle we make and remake our world as a people, and it culminates in the repetition (Wiederbolen), or appropriation, of a possibility from our past in a reinterpreted and renewed form, and it is only in the moment of vision that this authentic appropriation of our past is possible.

Repetition might be thought of as a dialogue with the past, or as Inwood suggests that we commit to a discourse with the past and its heroes, e.g., "Alexander or Plato makes certain suggestions"121 to us through their exploits or written words, and we "make a rejoinder to them." 122 Ultimately, through communal discourse as hermeneutic interpretation, repetition becomes a legitimate possibility of our Being, and through developing and deepening our interpretations of the world, which emerge through a confrontation with the past and past-as-present, we are in the position to authentically choose to choose ourselves through communal decision-making. Although we are beholden to our past this does not necessarily require that we honor or maintain it, further still it is not simply learning or memorizing our traditions, for this would be inauthentic confrontation with the past. Rather, we are only truly beholden to our heritage when we approach the past in order to see, understand, and beyond, envision ways in which it might be reinterpreted in light of our authentic potentiality-for-Being and taken up, through "repetition" in an authentic mode of historical appropriation, which both Heidegger and Huebner understand in terms of the human being's authentic enactment of its history through the process of historizing.

As this foregoing section indicates, Huebner's philosophy of curriculum is both phenomenological and ontological, and since it is interpretive, it is also, in the tradition of Heidegger's fundamental ontology of Being and Time, hermeneutic. The relevance of Huebner's introduction of phenomenology in education and curriculum studies as related to contemporary Heidegger scholarship in education can be traced to the philosophical development of such major educational theorists as Smith, Van Manen, and most particularly, David Jardine, whose writings focus on educational reform in terms of qualitative philosophical inquiry, which runs counter to empirical and social research in education and pedagogy Much of contemporary research, according to Jardine, views education as a practice wherein the privilege of theory and method reduce the student's authentic ("lived") social situation to "univocal terms that can be simply counted and recounted," 123 whereas authentic interpretative research, as related specifically to the hermeneutical project that we find in Huebner, attempts to tease out, interpret, and understand the intangible "evocative given in all its tangled ambiguity, to follow its evocations and entrails of sense and significance that

121 Inwood, Heidegger, 92.

122 Ibid., 92.

123 David Jardine, To Dwell with a Boundless Heart: Essays in Curriculum Theory, Hermeneutics, and Ecological Imagination (New York, NY: Peter Lang, 1998), 40-41. 
are wound up with it." 124 Thus, education cannot be authentically conceived as reducible to a strict methodology or "set of rules that need to be simply applied to an incident independently of the contribution that incident might have regarding what needs to be said"125 in light of the practical conditions of the lived experience of education, which proximally and for the most part, structure and guide the interpretation's unfolding.

Importantly, as related to Huebner's invaluable contribution to Heidegger studies in education, I have intimated within this paper a recent and emerging theoretical framework for research within contemporary educational scholarship in the post-structural movement to re-conceptualize the curriculum, which harbors a wealth of untapped potential, namely, the understanding of Being-in-the-world as unfolding through the attuned practice of "embodied" interpretation, understanding, and discourse as related to the life-practice of hermeneutics, or the "hermeneutics of facticity". In Being and Time Heidegger conceives the human being as it is always and already located within the world in a "factical" manner: "Facticity," as Heidegger reasons, "is a definite way of Being," "126 and this implies that "an entity 'within-the-world' has Being-in-theworld in such a way that it can understand itself as bound up in its 'destiny' with the Being of those entities which it uncovers within the world."127 Heidegger's foregoing description of "facticity," as employed within Jardine's qualitative work on education, as it is filtered through Huebner's philosophy of curriculum, suggests that the philosophy of education and the interpretation thereof must above all be performative: It must be lived and practiced in actions that are inseparable from the embodied, lived events within which our experiences of the world and others are inextricably grounded.

A philosophy as outlined embracing the "factical" unfolding of education as a practical immersion in the world, located within specific settings, bound up intimately with unique individuals, understands in advance that these concrete situations of learning cannot be grasped or communicated exclusively through rational, or calculative ("theoretical") forms of knowing, for their existential "truths" are beyond the purview of both analytic and empirical thought. Thus, contemporary educational research should show concern for the living process of education as a "kind of illuminating disclosing of life in the explicit actualization [Vollzug] of the movement of factical life."128 In Risser's analysis of the relationship between the bermeneutics of facticity and the human community, his philosophical claims might be related directly to Huebner's authentic understanding of education as described in this essay. Contemporary educational research would do well to "take its departure from

124 Ibid., 48

125 Ibid.

126 Heidegger, Being and Time, 82/56.

127 Ibid.

128 James Risser, "Philosophical Hermeneutics and the Question of Community," in Interrogating the Tradition: Hermeneutics and the History of Philosophy (Albany, NY: State University of New York Press, 2000), 22. 
factical life experience and always turn back to factical life experience," 129 and avoid practices that the attempt to transcend lived, factical experience through objective, abstract generalizations of students, educators, and the processes of learning. As Risser is careful to point out, in terms that echo Jardine, the hermeneutics of facticity is never reducible to a scheme or rigorous method (e.g., the scientific method in Dewey), for it is "neither exegesis nor an art of interpretation as in Schleiermacher and Dilthey; rather it is simply the operation of philosophy itself that catches hold of life in its activity."'130 With this understanding, in light of the ground covered, it is Huebner who inspires contemporary educational theorists to continue searching out the value in Heidegger's early philosophy as it might contribute to the betterment of our educational practices.

\section{The Potential Implication of the Individual-World Dialectic for Education}

Authentic education, conceived as unfolding within the individual-world dialectic does not adopt the procedural method of establishing goals, aims, and purposes of education in advance of learning experiences, as is consistent with product-process curriculum design. Rather, it is possible to imagine, in line with process-product models for curriculum, the goals and aims for learning and authentic standards for education always already immanent as potential in the authentic unfolding of the curriculum in progress, e.g., the for-the-sake-of-which that education is concerned with is not a determinate, immutable goal posited in advance of the learning. In line with the phenomenological-ontology of this paper, we might imagine goals and aims emerging through a process of hermeneutic interpretation, following a spiral structure, rather than a linear design for curriculum-making, educators begin with a fore-conception, or presupposition, concerning goals and outcomes, but these goals and outcomes are fluid and protean in nature, they change, evolve, develop and are reworked as knowledge and understanding of the student's needs, wants, desires, and abilities are revealed and interpreted by the educator. Although the educational aims for student achievement are set forth at the outset of the learning, they are more akin to informed suggestions, path-marks for learning, and are always subject to revision and elaboration as the educator deepens and clarifies her understanding of that which emerges from the learning experience.

As follows from above, there are crucial ethical implications bound up with authentic education concerned with the manner in which we dwell in community with others. Since the environmental design of the curriculum is grounded in the understanding of temporality and historicality, i.e., the authentic beritage, fate, and destiny of educators and students, learning transpires within an inclusive, multi-cultural environment, and beyond, depends for its authenticity on educator's embracing the inclusion of the language and cultural 
forms of knowledge that each student brings to the context of learning. The notion of heritage as embodying our living past, the unique collective ethos of the student's given culture, our collective ethos as members of a state and nation, the store of unique cultural possibilities that allow for the authentic projection into our future as destiny, testifies that education must avoid leveling down or excluding the diverse cultural histories and values of our students. Understanding heritage as the legitimate founding ground for our future growth and development should awaken educators to the necessity of transcending unethical and inauthentic practices and policies that socially, culturally, and linguistically marginalize students.

Authentic learning within the individual-world dialectic also embodies the ethical aspects of social-based learning, where students learn from each other and indeed teach each other in a variety of ways, and is concerned with the respectful exchange of ideas in ways that demonstrate care, tolerance, and a critical conscious awareness. The communal character of the classroom includes the all-important concern for moral development and engenders learning through a process of arduous and respectful discourse, which plays out in the process of accepting, rejecting, refining, validating, and honing the various interpretations that are offered up for debate in shared moments of problem-solving, which stress self-development and group development through communicative debate. There is recognition of the strengths and weaknesses that are either beneficial or detrimental to the personal development of the self and group. Educators and students work to arrive at common, agreeable solutions to the problems they attempt to solve through a process of critical debate, which is always rooted in the ever-changing needs of our students and their historical reality, which represents an ever-renewed ethical quest for knowledge, understanding, and meaning.

In addition to the student's heritage, she also brings a vast store of intellectual and emotional experience to the learning context, which holds vast potential to make a contribution to ever-growing, ever-developing communal archive of student knowledge. Meaning is constructed within the shared horizon of "perspectives" through the unfolding hermeneutic and heuristic activities wherein student's interpretations are composed of clusters of interpretations, and individual interpretations develop along with, and indeed because of, those with whom the student participates within the process of authentic learning. Thus, there is an all-important bridge constructed between prior knowledge, which is valued as legitimately contributing to the learning, and new knowledge. Authentic education also embraces alternative forms of knowledge in the curriculum, e.g., human wisdom, meditative thought, hermeneutic understanding, aesthetic insight, which allows educators and students to approach ontological aspects of their existence in a philosophical manner through a rigorous form of non-conceptual and non-systematic thought, which avoids the "subjectivist" trap of dualism. ${ }^{131}$

131 It is possible to associate understanding, as an alternative form of "knowing" the world, with a way of thinking that Huebner terms "human wisdom," which is akin to meditative 


\section{Concluding Remarks}

Scientific instrumentalism in education, of which Huebner is critical, is represented in the neural psychological-physiological research focused on what teachers should know about how students learn. As indicated, Huebner views education as becoming "overly dependent on scientific modes of thought for shaping values and legitimizing actions," 132 and this affinity for scientific thought is also present to teacher-training programs, where "future teachers are exposed to the psychological and developmental knowledge of the child and man to help develop knowledge of, attitudes toward, and skills for working with students." 133 Linda Darling-Hammond claims that educators must have an awareness about students' learning and its implications for teaching knowledge and skills, and this knowledge is gained by means of conducting scientific research in the following areas: Research on how teachers and students learn; Research on teacher learning and its affect on pedagogy and student outcomes; Research on learning conditions and teachers effectiveness in structuring and influencing learning; Research on brain development, language acquisition, and social development. ${ }^{134}$ Huebner, arguing against privileging empirical research in education, claims that the language "furthered and developed by the scientific study of the child"135 and educator ignores the more humane and philosophical issues of "the place of the adult in the child's world, the politics of adult-child relationships, the child's participation in the building of public worlds, and the art of interpretation about the meaning of life as people, children, and adults live together."136

Huebner is clear that authentic discourse on education reform cannot begin until there is the serious consideration of "the individual, the society and the culture or tradition." 137 In light of these aforementioned concerns, in "Curriculum as Concern for Man's Temporality," Huebner focuses specifically on the need for educators to gain a basic "awareness of historicity," which is intimately bound up with "man's temporality and the concern for it as the focus of curricular action."138 Huebner digs below the surface of the curriculum as currently conceived, "penetrating the realities that the everyday educator takes for granted," and illuminates, through a phenomenological

thought, as opposed to calculative thought. What John Gray writes about Heidegger's philosophy might well apply to Huebner's conception of rich, fecund, and deep contemplation within the classroom, for the advance in thought that both of these philosophers seek is to "learn to think non-conceptually and non-systematic yet with rigor and strictness about the nature of Being," within the overarching goal of avoiding "the subjectivity involved in separating human being and Being, subject and object." Heidegger, What is Called Thinking? Translator's introduction, xxv.

132 Huebner, "New Modes of Man's Relation to Man," 87.

133 Ibid., 87.

134 Linda Darling-Hammond \& Bransford, Preparing Teachers for a Changing World: What

Teachers Should Learn and Be able to Do (San Francisco, CA: Jossey-Bass, 2005), 1-39.

135 Huebner, "Toward a Remaking of Curriculum language," 35.

136 Ibid., 35.

137 Ibid., 41.

138 Huebner, “Curriculum as Concern for Man’s Temporality,” 132. 
approach in thought and language, the ways the "educator has decided to live in the world and what he sees as possible futures." 139 It is interesting to note that in Heidegger's reading of Nietzsche, Heidegger concluded that Nietzsche remained a metaphysician because he failed to transcend the conceptuallinguistic constraints of traditional metaphysics. This is why Heidegger required a new and unique language to address such issues as the oblivion of Being in philosophy; Huebner also seeks out a new and unique language with which to begin, perhaps for the first time, to authentically approach the phenomenon of education by means of new ways of speaking and thinking poetically, as opposed to merely being "socialized into the existing institutions or the language generated by them."'140

It is not about educators finding or inventing new words, resorting to catch phrases, or producing new terms for antiquated educational theories. Instead, what is required in the first instance is our awakening to the primordial power of "essential" language. Huebner, writing on language and teaching, speaks of the enduring nature of language in the Heideggerian spirit and seeks to understand the poetic, originary naming power of language as it might relate to inspiring authentic reforms in education. Language is not the equivalent of expressing or verbalizing knowledge through propositions, it is not merely a system of codes, signs, symbols, and signifiers, rather in its essence, "language is neither expression nor an activity of man," 141 for language in its authentic manifestation "speaks" through us in order to, by means of essential naming, bring the "presence of what was previously uncalled into a nearness." 142 Indeed, this is how Huebner conceives language, which allows us to bring forth what is concealed into the open by naming the world for the human being. In tracing Huebner's curriculum philosophy back to its origin or source, in relating his language and concepts to a unique way of "naming" the truth of our historical Being as related to our educational practices, I have tried to demonstrate a way in which educators might benefit through understanding Huebner's critical encounter with Heidegger's philosophy and draw inspiration from a reconceived understanding of education so that they might feel empowered to reconsider the ways in which they view students and themselves in terms of their own potentiality-for-Being as grounded in their historical realities, which hold the potential of offering unique possibilities for transcendence and emancipation in educational reform.

Department of Philosophy, College of Dupage, United States of America

\footnotetext{
${ }^{139}$ Huebner, "Toward a Remaking of a Curriculum Language," 37.

140 Ibid., 36

141 Heidegger, Poetry, language, Thought, 197-198.

142 Ibid., 197-198.
} 


\section{References}

Darling-Hammond, Linda, Preparing Teachers for a Changing World: What Teachers Should Learn and Be able to Do (San Francisco, CA: Jossey-Bass, 2005).

Dreyfus, Hubert, Being-in-the-world: A Commentary on Heidegger's Being and Time, Division I (Cambridge, MA: MIT Press, 2001).

Fried, Gregory, "Back to the Cave: A Platonic Rejoinder to Heideggerian Postmodernism," in Heidegger and the Greeks: Interpretive Essays (Bloomington, IN: Indiana University Press, 2006).

Grumet, Madeleine, "Existential and Phenomenological Foundations of Autobiographical Methods, in Understanding curriculum as phenomenological and deconstructed text (New York, NY: Teacher's College Press, 1992),

Heidegger, Martin, Being and Time, trans. by J. Macquarrie, E. Robinson (New York, NY: Harper \& Row, 1962). , What is Called Thinking?, trans. by J. G. Gray, F. Wiecks (New York, NY: Harper \& Row, 1968). Poetry, Language, Thought, trans. by A. Hofstadter (London: Harper \& Row, 1971). , The Concept of Time, trans. by William McNeill (Malden, MA: Blackwell Publishing, 1992). , The Metaphysical Foundations of Logic, trans. by Michael Heim, (Bloomington, IN: Indiana University Press, 1992). , Holderlin's Hymns: 'Germania and The Rhine, trans. by William McNeill (Bloomington, IN: Indiana University Press).

Huebner, Dwayne, "Towards a Remaking of Curriculum Language," in Heightened Consciousness, Cultural Revolution, and Curriculum Theory (Berkeley, CA: McCutchan Publishing Corporation, 1974). , The Lure of the Transcendent: Collected Essays By Dwayne E. Huebner (Mahwah, NJ: Lawrence Erlbaum Associates, 1999).

Inwood, Michael, Heidegger (Oxford: Oxford University Press, 1997).

Magrini, James, "Worlds Apart in the Curriculum: Heidegger, Technology, and the Poietic Attunement of Literature," in Educational Philosophy and Theory (forthcoming 2012).

McNeill, William, The Glance of the Eye: Heidegger, Aristotle, and the Ends of Theory (Albany, New York: State University of New York Press, 2000).

Jardine, David, To Dwell with a Boundless Heart: Essays in Curriculum Theory, Hermeneutics, and Ecological Imagination (New York, NY: Peter Lang, 1998).

Pinar, William, Understanding Curriculum as Phenomenological and Deconstructed Text (London: Routledge, 1992).

Risser, James, "Philosophical Hermeneutics and the Question of Community," in Interrogating the Tradition: Hermeneutics and the History of Philosophy (Albany, NY: State University of New York Press, 2000).

Wolin, Richard, The Heidegger Controversy: A Critical Reader (Cambridge, MA: MIT Press, 1998). 
Young, Julian, Heidegger's Later Philosophy (Cambridge, UK: Cambridge University Press, 2002). 